\title{
Digitality and Decolonization: A Response to Achille Mbembe
}

\author{
Victoria Bernal ๑
}

\begin{abstract}
This article explores questions of decolonization, in part through analyzing Belgium's Africa Museum. Bernal considers the role of academia and knowledge production, as well as the technological developments that may create new concentrations of power faster than decolonial projects can dismantle established hierarchies. She concludes that decolonization must address material questions of reparations and restitution, and that digital media have been transformative in ways that bring northern models of social existence closer to African ones. Having lived under colonizers, despots, and states of exception, Africans bring important knowledge and experience to twenty-first-century global struggles.
\end{abstract}

Résumé: Cet article explore les questions de décolonisation, en partie grâce à l'analyse du Musée de l'Afrique en Belgique. Bernal considère le rôle du monde universitaire et de la production de connaissances, ainsi que les développements technologiques qui peuvent créer de nouvelles concentrations de pouvoir plus rapidement que les projets de décolonisation ne peuvent démanteler les hiérarchies établies. Elle conclut que la décolonisation doit aborder les questions matérielles de réparations et de restitution et que les médias numériques ont été transformateurs de manière à rapprocher les modèles d'existence sociale du Nord de ceux de l'Afrique.

African Studies Review, Volume 64, Number 1 (March 2021), pp. 41-56

Victoria Bernal is Professor of Anthropology at the University of California, Irvine. Her scholarship explores questions about politics, gender, migration and diaspora, war, civil society and activism, and digital media. Her most recent book is Nation as Network: Diaspora, Cyberspace, and Citizenship (2014). Dr. Bernal co-edited the anthology, Theorizing NGOs: States, Feminisms, and Neoliberalism (2014). Professor Bernal has carried out ethnographic research in Sudan, Tanzania, Eritrea, Silicon Valley, and cyberspace. Her current project focuses on privacy, cybersecurity, and digital surveillance. E-mail: vbernal@uci.edu

(C) The Author(s), 2021. Published by Cambridge University Press on behalf of African Studies Association. This is an Open Access article, distributed under the terms of the Creative Commons Attribution licence (http:/ / creativecommons.org/licenses/by/4.0/), which permits unrestricted re-use, distribution, and reproduction in any medium, provided the original work is properly cited.

doi:10.1017/asr.2020.90 
Ayant vécu sous les colonisateurs, les despotes et les États d'exception, les Africains apportent un savoir et une expérience importante aux luttes mondiales du XXIe siècle.

Resumo: Este artigo debruça-se sobre temas relacionados com a descolonização, em parte através da análise do Museu Real da África Central, na Bélgica. Bernal analisa o papel desempenhado pela academia e pela produção de conhecimento, bem como os desenvolvimentos tecnológicos, que são capazes de criar novas concentrações de poder mais depressa do que os projetos de descolonização conseguem desmantelar as hierarquias estabelecidas. A autora conclui que a descolonização tem de abordar as questões materiais das reparações e da devolução de bens, e que os media digitais exerceram uma ação transformadora que coloca os modelos de existência social do norte mais próximos dos modelos africanos. Tendo vivido sob regimes coloniais, déspotas e estados de exceção, os africanos são uma importante fonte de conhecimento e de experiência para enfrentar as lutas globais do século XxI.

Key words: decolonization; knowledge production; anthropology; digital media; North/South relations; Afrofuturism; museums

(Received 24 May 2019 - Revised 24 June 2020 - Accepted 20 August 2020)

In his Abiola lecture on "Future Knowledges," Achille Mbembe addresses several major themes: What is the role of the academy in society? What should we do with institutions "inherited from a cruel past?" What would decolonizing knowledge entail? And, how does technological advancement, particularly digital technologies, enter into all of these questions?

\section{Decolonizing Institutions and Knowledge}

Mbembe introduces his lecture by saying he takes inspiration in part from recent student protests in South Africa. "At the core of these events," he says, "is the hope-especially among the younger generation-for something new, which would not simply be a repetition of what we thought we had got rid of...It is this hope that explains the renewed injunction to decolonize institutions, or for that matter, knowledge itself." Mbembe cautions, however, that we lack an idea of what decolonized knowledge might look like and that "the lack of a theory of knowledge [is] a potentially fatal weakness of the decolonizing project." He makes it clear that curricular reforms and mere substitutions of European materials and personnel with African ones is insufficient, and that a more profound unsettling of what constitutes knowledge and knowledge production is both necessary and already underway.

Debates about decolonizing institutions and knowledge production have succeeded in spawning entire new fields and perspectives such as subaltern studies and postcolonial studies, which have challenged the status of quo of research (Said 1979; Spivak 1988; Chakrabarty 2007). Prominent scholars 
have addressed the politics of knowledge in the context of global North/ South relations in ways that brought questions about who conducts research on what and on whom and from what perspective to the fore. While issues of imperialism and white supremacy are global, Africans have particular histories of racialization, enslavement, and colonialism. Accordingly, as Mbembe does, I will mainly consider decolonial questions related to Africa. Calls to decolonize education in Africa are not new, but the \#RhodesMustFall protests to which Mbembe refers that took place at the University of Cape Town in 2015 reverberated beyond the continent, bringing new attention and urgency to decolonial efforts (Ahmed 2020).

South African students developed a "decolonial framework centered on Pan-Africanism, Black Consciousness, and Black radical feminism” (Ahmed 2020:283). Others have approached decolonizing the university in varied ways. At Makerere University, for example, the MPhil/PhD program in Social Studies defined its decolonial project in terms of "seeing the world from African vantage points; ending the pervasive consultancy culture; and asking context-specific home-grown questions" (Serunkuma 2019:119). The focus on "consultancy culture" at Makerere goes to the material conditions of scholarship in Africa, where institutions and individual scholars often depend on funding from the global North. Knowledge production is then tied to external research agendas rather than to African priorities. I observed similar struggles in Tanzania, where I found that "the practices of international donors have regime-like effects" enabling and constraining the work of activists and academics (Bernal 2017:39). As these examples and Achille Mbembe suggest, what must be done to decolonize, and what the future of such knowledge production will look like are ongoing questions. Perhaps rather than any blueprint, what is needed most is the opportunity for radical experimentation.

As an anthropologist, I am convinced that decolonizing knowledge will not be possible without decolonizing society. Imperial prejudices and practices regarding Africans still operate powerfully and globally at various scales from the interpersonal to the international. Having now been married for decades to an African and raising our "bi-racial" daughters (who are perceived as Black in the U.S.), I have an intimate experience of racism that complements my academic knowledge. Perhaps we need a theory of antiblackness before we can have a theory of knowledge that can undergird processes of decolonization. The ways that global inequalities are rationalized and perpetuated in relation to Africans and people of African descent have proven resilient and flexible, changing in sync with shifts in the global political economy and the rise of neoliberalism. I am struck, for instance, by a 2019 campaign on CNN International, \#myfreedomday, which features an ad focused on "child slavery" in Africa. At the start of the ad, a voiceover mentions the location as Ghana but, without any further information or contextualization, the scenes shown are typical of how some part of Africa is used to represent the whole, a generic Africa, too often depicted in terms of a negative attribute, lack, or need. The ad shows a fisherman's pirogue from 
which boys are diving down into the water. The narration likens these boys to slaves who need to be freed.

I am opposed to the exploitation of children, of course. What bothers me about this publicity campaign on "child slavery" is how it presents Africans as the major exploiters or even economic criminals about whom global publics should be concerned. It does so, moreover, while failing to make any reference to the far more powerful and pervasive exploitation by corporate capital, which no doubt, if we researched the context of the de-contextualized fisherman and boys, are a key part of the economic forces that have created their desperate circumstances. Western wealth, power, and responsibility are understood here only in terms of benevolent rescue and philanthropic engagement. There is no sense of any wider relationships that connect Africa and the rest of the world, particularly the global North. Moreover, the implied similarity of these boys' circumstances and the historic Western enslavement of Africans obscures the fact that Western slavery was an institution codified in law, whereas, however deplorable, the Ghanaian "slavery" practices shown are informal and illegal.

The on-screen narrator who likens the boys to slaves is himself an African. Thus, this representation so convenient to Western power appears to the audience as authentic and detached from Western authorship. We might consider this a form of faux decolonization of knowledge, in which, as Mbembe notes, "decolonization is easily reduced to a matter of origins and identity, race and location. What confers authority is where one comes from, the putative community one belongs to, not the truth validity of the claims being made." By faux decolonization I refer to changing the superficial appearance of information, rather than its substance or meaning. Faux decolonization is not simply a failed attempt at decolonization, then, but an insincere one.

In Mbembe's discussion of decolonization as involving de-centering Europe and theories derived from European experience, I am puzzled that Mbembe does not mention the idea of "Theory from the South" proposed by the Comaroffs, drawing on their own knowledge of South Africa (Comaroff \& Comaroff 2012). The Comaroffs' proposal is compelling because it reverses the assumption that everything unfolds first in the global North while the South lags, always following behind and doomed to play catch-up. Theory from the South suggests that global trends can and do originate in the South. Therefore, theories based on African conditions and experiences can provide insights into other regions and global processes. I used this argument as a rationale for developing a graduate seminar at my university on "Global Africa," designed not as an area studies course, but as an exploration of how Africans are in the center of global issues, even if some theories and reporting on these issues treat Africa as marginal or ignore it altogether. Later in his lecture, Mbembe presents another sense in which Africans have prefigured global shifts when he suggests that long-standing African conceptions of the human are analogous to emerging theoretical constructions of the posthuman. 
Where Mbembe mentions anthropology, it is in terms of the historic failures of the discipline to fully acknowledge "Others as thinking and knowledge-producing subjects." Much contemporary anthropology, however, reflects the fruits of scholarly engagement over the past three decades in reflexively challenging the discipline's own practices. Feminist scholars such as Donna Haraway (1996) and Michelle Rosaldo and Louise Lamphere (1974) inside the discipline as well as others outside it (Moraga \& Anzaldua 2015; Mohanty 1988; Collins 2008), among others, were key to unsettling the basic premises of much scholarship. James Clifford and George Marcus's (1986) landmark volume sparked controversies within departments and change within the discipline. The contributions of feminist scholars as well as those of African diaspora scholars to these transformations have been underestimated (Harrison 1997; Allen \& Jobson 2016). Africanist anthropologists like myself were influenced by Franz Fanon (1963), Walter Rodney (2018), and Manning Marable (1999) among others, and later by Paul Gilroy (1993) and Stuart Hall (1997), as well as by the subaltern and postcolonial studies scholars mentioned earlier.

Anthropologists now analyze the World Bank, NGOs, the U.S. military, corporations, and various other powerful institutions, and they conduct research in the global North. Change in the discipline is happening, furthermore, because the ranks of anthropologists have come to include members of the populations that once were merely the subjects of study. There has been a conscious attempt to consider how anthropology has served imperial power and to decolonize the discipline, inventing new ways of approaching and communicating our work (Bejarano et al. 2019; Madison 2019; Harrison 2008). Much more remains to be done to decolonize anthropology, but I invite Mbembe to compare twenty-first-century anthropologists' ideas about Africa to those of political science, art history, or other disciplines, where attempts to counter underlying Eurocentric assumptions have had less success in bringing about transformation.

While contemplating possible responses to Mbembe's lecture, I happened to be living in Brussels when a major Belgian decolonization project was unveiled. Mbembe does not speak about art or about the institution of the museum, but clearly any decolonization of knowledge must encompass them. The Belgian museum's attempt to decolonize its representation of Africa is problematic in instructive ways.

\section{Decolonizing? The Africa Museum at Tervuren}

In 2018, after being closed for years, the Africa Museum at Tervuren (also known as the Royal Museum for Central Africa) re-opened after a process of decolonization that was celebrated with great fanfare and national media attention in Belgium. The focus on decolonization was quite explicit in media coverage and on the museum's website, which states that, "the big challenge was to present a contemporary and decolonised vision of Africa in a building 
which had been designed as a colonial museum." (https://www. africamuseum.be/en/discover/renovation).

Having heard such exciting news about the decolonization of the museum, I was therefore surprised on opening night to find African masks and other objects in conventional display cases, and to see the inclusion of exhibits of African wildlife specimens, such as a life-size stuffed zebra. Ultimately, why this decolonization project fails in my view, however, is not due to which objects are displayed or excluded. As it happens, an entire room in the museum is paradoxically devoted to displaying items removed from the other exhibits in the decolonization effort. How this decolonization really fails, though, is through the neglect of context. A glaring example of this is that slavery is only addressed in a very small display in one corner of the museum. Slavery is to a great extent a foundation of the world we all inhabit today. It dehumanized Africans in ways that endure. The slave trade also created a world where for generations now people of African descent have been integral to societies of North and South America and the Caribbean. In the museum, the text accompanying the slavery exhibit begins "Between 1520 and 1866 an estimated 12 to 13 million Sub-Saharan Africans are enslaved and brought to America." This passive voice is used throughout the text that thus avoids any mention of who was enslaving Africans and profiting from it. Slavery and colonialism helped establish the huge economic inequalities that exist between Africa and the global North. Any decolonization effort that erases the profound legacies of slavery and colonialism rather than addressing these relationships will be counterproductive.

In fact, for Europe and North America, decolonization in relation to Africa might require a decolonization of wealth, that is, a societal reckoning with all the ill-gotten gains of slavery and colonialism. It might require national and international conversations around processes of restitution, reparations, and repatriation. But I will leave that thought and return to my consideration of the Africa Museum.

The museum includes a few references to contemporary technology in Africa. In the center of one room is an enormous robot. The robot was designed by engineer Thérèse Izay Kirongozi, who is billed as the president of a Congolese association of women engineers, called "Women's Technology." Robots such as this one are used to manage traffic in several Congolese cities. The imposing and intriguing figure of the robot is represented more or less as another cultural artifact or work of art, when it could be used as an entry point into the dynamic and inventive technological culture in Africa. Technology is taken up in a location separate from the main exhibits on a lower level of the museum building. There is a space devoted to African websites called AfricaTube (presumably a play on YouTube). The distinct separation of this room from the museum proper suggests an ambivalence or uncertainty on the part of the directors and curators as to how the digital relates to African cultures. In some sense, African digital production is thus both included and excluded from the museum. 
A plaque on the wall explains that "AfricaTube is a virtual library on contemporary digital Africa that connects the museum with the afrocyberspace. A group of youngsters search the web for blogs, audiovisual material, platforms, and music from Africa and the African diasporas." The exhibit itself consists of screens, where, with little context, African online content is being shown. Rather curiously, the museum's webpage devoted to AfricaTube is not interactive and includes no links to any of the websites. One gets little sense from AfricaTube as to what the internet has meant to Africans and African diasporas, and how connectivity fits into people's lives. Keeping this material separate from the rest of the displays seems like holding modernity at arm's length and preserving a primordial Africa of masks and fetishes, rather than recognizing the synergy and syncretism of African life, incorporating the new and re-invigorating the old in ongoing processes of transformation.

Rather than simply choosing more carefully what African objects to exhibit and to describe in terms of their uses and origins, the museum needed to provide a discussion of the collection of African objects as a Western practice. Decolonizing by contextualizing would involve critically examining how these objects were collected, under what conditions, by whom, and how they came to be possessed by the museum and selected for display. As Christine Mungai (2018) observes "We should never imagine that seizure of these objects was incidental or adjacent to the colonising enterprise -it was part and parcel of it." A reflection on the social, political, and economic relationships around the acquisition and exhibition of these objects would have helped break down the wall or, more specifically, the glass display case between Belgian viewers and the Africa on display, showing how they are deeply entangled.

Particularly telling for me was a small explanatory text in one room labeled "Afropea," a conjugation of African and European. The text explained to museum-goers that Africans first settled in Belgium around 1960 when the Belgian Congo gained independence, with a larger migration taking place from $2000 \mathrm{on}$. The narrative concluded with the observation that Africans have "left their mark on Belgian society." Thus, even as it acknowledges the existence of African Belgians, the text makes clear they are not members of Belgian society even after generations, but outside it, having an effect on it. This formulation was particularly striking to me since I was living in Brussels, where Africans and people of African descent were encountered on a daily basis, seemingly in all walks of life, so-called mixed couples were common, and every group of school children I saw included children of African descent. In the museum, Belgium was not only constructing a distorted image of Africa, it was distorting its own image by denying the multicultural character of its society in its explanation of "Afropea."

Closer to home, as a professor in the University of California system for nearly three decades, I have witnessed a colonization of the university by corporate capital and an associated devaluation of those fields of knowledge most engaged in decolonizing projects, the humanities and social sciences. 
Interdisciplinary endeavors such as Ethnic Studies, Gender Studies, and African Studies are particularly undervalued and starved for resources. There are huge struggles to be faced in "creating a less provincial and more open cosmopolitan pluriversalism" and "transcending our disciplinary divisions," as Mbembe advocates. As an American in the age of Trump and a temporary resident of "fortress Europe," I see a heartbreaking irony in Mbembe's call to "radical hospitality, co-belonging and openness." Northern allies of African decolonization projects (among whom I count myself) clearly have their work cut out for them in their own home institutions and countries. Of course, many students and faculty have been steadily working to change the academy, often in informal and less visible ways, such as organizing reading groups, workshops, film series, and other events where innovation is much easier and faster than formal curricular reform or changing hiring and review practices. These kinds of grassroots intellectual efforts and creativity in the margins are vital, serving in the moment and prefiguring and propelling larger scale shifts.

After setting the stage with momentous questions about the university, knowledge, and decolonization, Achille Mbembe turns to consider how digital technologies might contribute to decolonizing projects. (Here Mbembe interweaves ideas about the brain and possible neurological changes that I will leave for others to address. In my view, neurological issues do not seem pertinent to the core concerns raised in the speech and, moreover, they lie outside my own expertise.) As a scholar of digital media since the 1990s, I am interested in the question of how such technological advancements might help bring about a decolonial future, and I now turn to a critical engagement with Mbembe's ideas on this.

\section{The Digital Fetish and the Hidden Powers of Technology}

Mbembe observes a vital affordance of digital media-that knowledge can no longer be "so easily restricted by organizational apparatuses." He notes that "Extra-institutional knowledge is unbounded, uncontainable, and easily searchable." But as he also implies, Googling may provide knowledge but not necessarily an education, which involves "how to think properly, the questions that are the right ones to ask." If we are thinking about decolonizing knowledge, Google might be another good place to start. Far from being the neutral knowledge-retrieval operation it appears to be, Google's algorithms determine people's search results, and those algorithms can reflect the cultural biases and assumptions of coders and the data sets on which the algorithms are developed (Browne 2015). In terms of considering how digital technologies transform how we know things, the secret work of algorithms and the domination of global information circuits by monopolistic corporations such as Google and Facebook in constructing the digital world people encounter and inhabit to an ever greater degree is no small matter.

Mbembe seems to suggest that digital media have speeded up the pace of change among disciplines, through processes of specialization and 
fragmentation as well as through the productivity of interdisciplinary thematic imagination. He sees "historic antagonisms between the sciences and humanities disciplines" breaking down, partly due to the recognition that humans do not uniquely stand apart from non-human entities. Mbembe cites a "rejection of the Cartesian dichotomy between subject and object, society and nature, human and nonhuman, living and non-living entities." In his inspired analysis of these evolving notions of the human and the breaking down of previously held ideas about dichotomies, including the human and the technical, Mbembe's discussion of knowledge becomes unmoored, however, from the bold provocations about decolonization with which he began.

This is unfortunate, because decolonizing the university, knowledge itself, and theories of knowledge is inescapably a political project that must acknowledge the diversity of humans' conditions of existence and experience, while addressing differentials of power and resources. In that sense, decolonization is fundamentally a grounded project, and therefore, more of an ethnographic project than a philosophical one. The vibrant diversity and the profound inequities among people and societies are obscured once we operate at the abstract level of the universal human or the posthuman. We therefore lose sight of Africans and of the just demands of African students and youth for a better education and a better world with which Mbembe began his remarks.

Under the heading "knowledge in a computational age," Mbembe raises critiques of current technological developments that resonate with my concerns about corporate algorithms. He says, "Knowledge is reduced to an understanding of what lies behind people's decision-making, their responses to marketing." However, Mbembe leaves the origin of these ideas and their practitioners out of the proverbial equation, as if we all equally share in this new global computational culture. Digital culture and digital technologies are not free-floating and global. They are not based in the ether or the cloud; rather, they are rooted in particular national power centers, notably the U.S. and China, and also in the giant corporations, Google, Facebook, Apple, and Amazon, that are themselves huge new power centers. These powerful corporations are mainly based in the twentieth- and twenty-first-century imperial power, the United States. Technological developments may create new concentrations of power faster than decolonizing projects can dismantle established hierarchies.

Technology is not neutral when it is designed, owned, and managed by a small group of Western elites. In her ethnography about the clientele of Ghanaian cybercafes, Jenna Burrell calls these Africans "invisible users," defined in part by "a lack of accommodation by those in power (ranging from distant technology designers and network administrators to local politicians and other authorities)" (2012:8). In my ethnography of Eritrean diaspora websites, I highlighted Eritreans' creativity in embracing and adapting to their own purposes digital media that were not developed with the needs of Africans or refugees in mind (Bernal 2014). In the course of that research, I also developed the concept of "infopolitics" to draw attention to 
the ways power is exercised through the management of information and communication. I argued that "power, violence, and the politics of knowledge need to be placed at the center of analyses of the internet" (2014:8). Inspired in part by Mbembe's (2003) concept of "necropolitics," my concept of infopolitics draws attention to the way in which power is exercised through secrecy, censorship, and processes of legitimation and de-legitimation that operate to shape who is entitled to speak about what to whom, which narrative is authoritative or believable, and other processes that construct the production and circulation of what is often described as "information."

Mbembe is surprisingly optimistic about digital transformations in Africa. This is striking to me for several reasons to which I will turn later, not least of which is that this optimistic outlook comes from the author of "necropolitics." Mbembe introduces the notion of "Afro-computation," a term for what he identifies as "a silent techno-computational revolution" taking place in Africa and "paving the way for an Afropolitan aesthetic sensibility." Mbembe rightly observes that the embrace of digital technologies has swept the continent, particularly through the mobile phone. He states, "In Africa, this device is not only a medium of communication. It is also a medium of self-stylization and self-singularization...It has become an extension of one's being, a container of lives it in turn shapes" (italics original). But, in the intimate relation to the cell phone and its role as an object of status and style, Africans are not unique. Many people in the global North fetishize their mobile devices and keep them close at all times. Starting with the BlackBerry, these devices were also status objects with symbolic value. Mbembe's observation that the cell phone presents "the world as cinema" to Africans is consistent, moreover, with the global rise of Instagram, Pinterest, and TikTok.

I think there is, nonetheless, a significant distinction between Africans' experiences of digital technologies and the experiences of people in the global North. In the global North, other personal devices-desktops, laptops, and iPads-first made digital connectivity central to people's daily lives; these were then displaced in favor of the cell phone. In contrast, for many Africans, the mobile phone is their first personal digital device. Africans thus may typically rely on instant messaging rather than communicating through email. Of course, many Africans had access to the internet in cybercafes or places of employment before, but those more public experiences and relations to digital technology are quite different from possessing a continuously and privately accessible personal device.

What is most distinctive about Africans' relationship to the digital, however, is the high value Africans have always placed on social relationships and networking to begin with. In my own work on the websites established by Eritreans in diaspora, I noted that Eritreans were already intensively and extensively engaged in transnational social and political networks before the advent of the internet (Bernal 2006). They became early adopters who quickly exploited the affordances of computer-mediated communication to suit their own needs because they already had such vibrant social networks 
off-line (Bernal 2014). For people in the global North, taught to think of themselves as independent individuals operating within circumscribed worlds of public and private, digital media have been culturally transformative in ways that perhaps bring the Northern model of social existence closer to an African one. This is a world of concentric, overlapping, intersecting, layered, and ever-growing networks whose maintenance and expansion constitutes a kind of life project. The shift to this networked sociality in the global North could be taken as an example of Theory from the South, where African social forms and values prefigure developments elsewhere. Perhaps it is no coincidence that the intensification of social networking in the global North has accompanied rising economic precarity and the "gig" economy, which create conditions not unlike those that characterize informal economies in Africa.

\section{Africa, Digitality, and Posthumanism}

Returning, if rather obliquely, to the question of decolonization, Mbembe argues that we can think productively about the digital by relating it to African precolonial cultures. (Precolonial cultures of course are only "precolonial" in retrospect; but in any case, it is easier to decolonize the past where colonization had not yet happened, than to find decolonized contexts in the present.) I read Mbembe, therefore, not as speaking of African history here so much as of some fundamental Africanness unspoiled by Western intervention. What Mbembe draws attention to are African understandings of the fluidity among categories, in contrast to simple dichotomies between organic and inorganic, or humans and other living entities, as well as to African beliefs in worlds beyond human perception. No ethnography has captured this sensibility as well as Ben Okri does in his novel The Famished Road (1991). I suspect, moreover, that the arts (rather than conventional academic disciplines) may be the key to the kinds of genre-busting and fearless experimentation needed for constructing decolonial futures. Mbembe, as I understand him, suggests that Africans have long had an outlook akin to posthumanism. He says, "It is nowadays commonsense to argue that the technological devices that saturate our lives have become extensions of ourselves. The novelty is that in the process, they have instituted a relationship between humans and other living things or vital things African traditions had long anticipated."

Drawing on the work of anthropologists, Mbembe observes that "knowledge for the sake of knowledge was a key feature of [African] social existence." He concludes this discussion with the statement, "It is as if the Internet was speaking unmediated to this archaic unconscious or to these societies' deepest and hidden brain." I only sense partially what he means, and I am uncomfortable with the metaphors of brain and unconscious. I suspect his argument is that African societies were especially receptive to experiencing life through digital media because of enduring and fluid African cosmologies that allow for expansive imaginaries and tolerate ambiguity. The virtual, the compression of time and space, thus map onto existing African 
understandings rather than challenging them. Katrien Pype and Sasha Newell (this collection) develop similar ideas when they situate mobile telephony in the context of witchcraft.

It is worth considering, nonetheless, how addictive digital devices and social media have proven to be globally. I heard one of the early founders of social media interviewed in Silicon Valley who said that in the beginning no one involved had any idea just how important social media would turn out to be, but it scaled so fast because it "tapped into our human nature." By this, the developer meant humans' fundamental sociality and need for connection, recognition, and belonging. Of course, these basic human needs are expressed and met in different forms in different contexts and cultures. How the affordances of digital media are exploited and adapted by people who thus reproduce and transform long-standing values, practices, and institutions raises many interesting questions scholars have only begun to explore.

Mbembe explains that "in old African traditions" people "were constantly in search of a supplement to their humanhood," sometimes adding "attributes or properties taken from the worlds of animals, plants, and various objects." But, he says, modernity rejected that, clearly distinguishing the human from everything else. He draws an analogy between precolonial African worldviews and our relation to digital devices, as they become part of who we are and give us new powers in some sense. I would argue that what is most important about digital media is not how humans relate to their devices, or even how they relate to themselves in a new way through their devices, but how these devices and their associated affordances, apps, and platforms enable and mediate social relationships in new ways. Thus, where Mbembe sees "the emergence of an entire different kind of human being we have not seen before," I see the emergence of new forms of social and political relationships as more significant. It may simply be that Mbembe as a philosopher is oriented to consider the human, and I as an anthropologist am trained to attend to the social. Perhaps we are speaking of the same things using different language.

\section{Digital Necropolitics}

Where I clearly part from Mbembe, as I hinted earlier, is in his optimistic view of digital transformation. I would like to ask him: What happens when necropolitics are digitized? What happens when commandment has the tools of algorithms and digital surveillance to bring to bear on "relations of subjection"? (Mbembe 2003:24). Pype (2016) reports that Congolese were initially suspicious of mobile phones because they first were used by government officials and security personnel. Many African states are known to practice internet shutdowns at times of political mobilization so that people are cut off from information about what is happening, and civil society organizations and social movements are impeded in their efforts to organize protests or mobilize people around their cause. Ethiopia is reported to engage in extensive computer surveillance, even installing spyware on the 
computers of Ethiopians in the United States (Electronic Frontier Foundation n.d.). In Eritrea, Isaias Afewerki's regime employs the strategy of severely restricting its peoples' access to the internet at all and keeping bandwidth so low that functionality is severely limited. Smart phones in Eritrea only have connectivity when the owner buys connection time to use in an internet café. The South African state is an early adopter of biometric data, which is now used in its passports.

The 2013 revelation by Edward Snowden about the U.S. government's digital mass surveillance programs was the turning point for me. Until that time, my research was focused on the creative ways Eritreans used digital media to engage in national politics and circumvent state control over media and information. After Snowden, I began to focus my digital research less on how ordinary and marginalized people were empowered by the internet and began to analyze how powerful states and corporations enhanced their powers by digital means. The recent manipulations of American voters by Russia through Facebook in the 2016 U.S. presidential election and the suspicions about China extending its surveillance activities globally through Huawei's 5G infrastructure suggest that we are only beginning to understand the dangerous capabilities that exist alongside the promises of the democratization of knowledge and power the internet can offer.

Digital capabilities can as easily serve as a means of multiplying and extending imperial, state, and corporate power as they can serve any process of decolonization or democratization in Africa or elsewhere. The digital constitutes a frontier on which struggles for democracy, for equality, and civil rights are being and will have to be fought. The internet and social media are not what they appear to be, not what those who pioneered the world wide web intended them to be, and no longer what I and many scholars initially understood them to be (Bernal 2020). Perhaps those more marginal populations in Africa and elsewhere who have had less access to connectivity will have an advantage, in that up to now their lives have not yet been fully captured in digital records. Movements around digital rights are gaining ground, resulting in the EU's General Data Protection Regulation, for example, that went into effect in May of 2018. Perhaps movements setting limits on the collection and retention of personal data will make safer options available to latecomers to the digital revolution. Having lived under colonizers, despots, and states of exception, moreover, Africans may bring important knowledge and experience to the twenty-first-century struggles for digital rights. I turn finally to the conclusion of Mbembe's lecture.

\section{Afrofuturism, Wakanda Forever, and Decolonization}

Mbembe ends on an Afrofuturist, Wakanda-esque note (although he gave this talk in 2016 and the film Black Panther only appeared in 2018). Mbembe turns to Africa as the source of valuable minerals and land, asserting that Africa is "the only place on Earth where people can still come and begin anew and where the potential for the human species is still high." Afrofuturism is, 
indeed, one form that imagining decolonization can take. Afrofuturistic imaginaries help to envision possibilities beyond the merely "postcolonial." For some viewers, the fictional Wakanda represents what Africa might be like if it had never been colonized. In an interview, Chadwick Boseman, the actor who plays the Black Panther (aka King T'Challa), says that in the process of creating the character, some people thought T'Challa should speak with a British accent even though Wakanda had never been colonized (Yamoto 2018). Boseman countered this, arguing, "Well, why would he have gone to study anywhere? Who could educate him outside Wakanda?" and the cast ultimately went on to use a range of authentic African accents. Boseman's comments connect to the themes of decolonizing education with which Mbembe began and resonate with the idea of Theory from the South in asserting that knowledge, education, and expertise need not come to Africans from outside; Africans are knowledge-producers in their own right.

Mbembe, in turning from the complexity of Africa's social and cosmological constructions to its raw resources and to humanity as a species, seems to bend temporality so that an uncorrupted precolonial Africa of unlimited potential coexists with a future Africa. Africans have never fully benefitted from Africa's resources, however. In relation to the digital revolution, it is significant that much of the rare mineral coltan, used in cell phones, comes from African mines (Smith 2011). Yet the extraction of coltan has facilitated the enormous wealth amassed in Silicon Valley and other tech hubs of the global North. In the fantasy land Wakanda, the rare mineral vibranium forms the basis of a powerful African civilization, but so far into the twenty-first century, African minerals are still extracted to serve and profit consumers and corporations of the global North as was done under colonialism.

In reading and analyzing at my leisure the text of Mbembe's speech, which he has said is provisional and a "thin sketch," I have perhaps been too critical, holding his statements accountable for an authority he did not intend them to have. Mbembe here, as always, is stimulating and provocative, offering arguments that are rich with original ideas and insights. He inspires us to think about the future and the past, the workings of knowledge production and circulation, relations of North and South, and scientific and technological transformations, and to imagine the vast potentials to be realized through decolonization.

\section{Acknowledgments}

I am grateful to the University of Leuven, Belgium, for a Senior Research Fellowship at the Institute for Anthropology in Africa in 2018-19, during which time I composed this essay. Many thanks to Katrien Pype, my sponsor and collaborator at KU Leuven. I thank Katrien Pype and Sasha Newell for their insightful comments on an early draft of this essay, and three anonymous reviewers for their suggestions on the penultimate draft. 


\section{References}

Ahmed, A. Kayum. 2020. "\#RhodesMustFall: How a Decolonial Student Movement in the Global South Inspired Epistemic Disobedience at the University of Oxford.” African Studies Review 63 (2): 281-303.

Allen, Jafari Sinclaire, and Ryan Cecil Jobson. 2016. "The Decolonizing Generation: (Race and) Theory in Anthropology since the Eighties." Current Anthropology 57 (2): 129-48. https://doi.org/10.1086/685502.

Bejarano, Carolina Alonso, Lucia Lopez Juarez, Mirian Mijangos Garcia, and Daniel Goldstein. 2019. Decolonizing Ethnography: Undocumented Immigrants and New Directions in Social Science. Durham, North Carolina: Duke University Press.

Bernal, Victoria. 2006. "Diaspora, Cyberspace, and Political Imagination." Global Networks: A Journal of Transnational Affairs 6 (2): 161-80. (Special Issue on "Return to Cyberia: Technology and the Social Worlds of Transnational Migrants").

- 2014. Nation as Network: Diaspora, Citizenship, and Cyberspace. Chicago: University of Chicago Press.

— 2017. "NGO Fever and Donor Regimes: Tanzanian Feminist Activism within Landscapes of Contradictions." In Cultures of Doing Good: Anthropologists and NGOs, edited by Amanda Lashaw, Christian Vannier, and Steven Sampson, 37-55. Tuscaloosa: Alabama University Press.

— 2020. "The Aesthetics of Cyber Insecurity: Displaying the Digital in Three American Museum Exhibits." In Futureproof: Security Aesthetics and the Management of Life, edited by Asher Ghertner, Daniel Goldstein, and Hudson McFann, 33-62. Durham, North Carolina: Duke University Press.

Browne, Simone. 2015. Dark Matters: On the Surveillance of Blackness. Durham, North Carolina: Duke University Press.

Burrell, Jenna. 2012. Invisible Users: Youth in the Internet Cafes of Urban Ghana. Cambridge: MIT Press.

Chakrabarty, Dipesh. 2007. Provincializing Europe: Postcolonial Thought and Historical Difference. Princeton: Princeton University Press.

Clifford, James, and George Marcus. 1986. Writing Culture: The Poetics and Politics of Ethnography. Berkeley: University of California Press.

Collins, Patricia Hill. 2008. Black Feminist Thought: Knowledge, Consciousness, and the Politics of Empowerment (Routledge Classics). London: Routledge Press.

Comaroff, Jean, and John Comaroff. 2012. "Theory from the South: Or, how EuroAmerica is Evolving Toward Africa." Anthropological Forum 22 (2): 113-31.

Electronic Frontier Foundation. n.d. https:/ /www.eff.org/cases/kidane-v-ethiopia.

Fanon, Franz. 1963. The Wretched of the Earth. New York: Grove Press.

Gilroy, Paul. 1993. The Black Atlantic: Modernity and Double-Consciousness. Cambridge: Harvard University Press.

Hall, Stuart. 1997. Representation: Cultural Representations and Signifying Practices. Thousand Oaks, California: Sage Publications.

Haraway, Donna. 1996. Simians, Cyborgs, and Women: The Reinvention of Nature. London: Free Association Books.

Harrison, Faye. 1997. Decolonising Anthropology: Moving Further Toward an Anthropology of Liberation. American Anthropological Association.

. 2008. Outsider Within: Reworking Anthropology in the Global Age. Champaign: University of Illinois Press.

Madison, D. Soyini. 2019. Critical Ethnography: Methods, Ethics, and Performance. Thousand Oaks, California: Sage Publications. 
Marable, Manning. 1999. How Capitalism Underdeveloped Black America. Boston: Southend Press.

Mbembe, Achille. 2003. "Necropolitics.” Public Culture 15 (1): 11-40.

Mungai, Christine. 2018. "Who are Western Museums Guarding African Artefacts From? From the Very Cultures that Created Them?” Aljazeera.com, December 3. https:/ /www.aljazeera.com/indepth/opinion/western-museums-guarding-afri can-artefacts-181203115612952.html.

Moraga, Cherrie, and Gloria Anzaldua, eds. 2015. This Bridge Called My Back: Writings By Radical Women of Color, $4^{\text {th }}$ Edition. Binghamton: State University of New York Press.

Mohanty, Chandra. 1988. "Under Western Eyes: Feminist Scholarship and Colonial Discourses." Feminist Review 30 (1): 61-88. https:/ / doi.org/10.1057/fr.1988.42.

Okri, Ben. 1991. The Famished Road. New York: Doubleday.

Pype, Katrien. 2016. “'[Not] talking like a Motorola': Mobile Phone Practices and Politics of Masking and Unmasking in Postcolonial Kinshasa." Journal of the Royal Anthropological Institute 22: 633-52.

Rodney, Walter. 2018. How Europe Underdeveloped Africa. New York: Verso.

Rosaldo, Michelle, and Louise Lamphere, eds. 1974. Women, Culture, and Society. Stanford: Stanford University Press.

Said, Edward. 1979. Orientalism: $25^{\text {th }}$ Anniversary Edition. New York: Vintage Books.

Serunkuma, Yusuf. 2019. "The Academia is a Marketplace: History, Context and Decolonization at Makerere University." Proceedings of the African Futures Conference. https://doi.org/10.1002/j.2573-508X.2018.tb000012.x.

Smith, James. 2011. "Tantalus in the Digital Age: Coltan Ore, Temporal Dispossession, and 'Movement' in the Eastern DR Congo." American Ethnologist 38 (1): 17-35.

Spivak, Gayatri. 1988. "Can the Subaltern Speak?" In Marxism and the Interpretation of Culture, edited by Cary Nelson and Lawrence Grossberg, 271-316. Champaign: University of Illinois Press.

Yamato, Jen. 2018. "How Chadwick Boseman Brought Power and Purpose to Marvel's 'Black Panther.'” Los Angeles Times, February 8. https://www.latimes.com/enter tainment/movies/la-ca-mn-black-panther-chadwick-boseman-interview-20180208story.html. 